\title{
GERMINATION AND INITIAL GROWTH OF COWPEA CULTIVARS UNDER OSMOTIC STRESS AND SALICYLIC ACID ${ }^{1}$
}

\author{
EDILENE DANIEL DE ARAÚJO ${ }^{2 *}$, ALBERTO SOARES DE MELO ${ }^{2}$, MARIA DO SOCORRO ROCHA ${ }^{2}$, REBECA \\ FERREIRA CARNEIRO ${ }^{2}$, MAURISRAEL DE MOURA ROCHA ${ }^{3}$
}

\begin{abstract}
Cowpea is one of the major food crops in Northeast Brazil, where it is commonly cultivated in the semi-arid regions with limited water availability. It is important to study the elicitors associated with cowpea to mitigate any deleterious effects of abiotic stress on the initial establishment of this crop. In this study, we aimed to evaluate the morphophysiological changes in cowpea cultivars under osmotic stress with seeds soaked in salicylic acid. The germination test was conducted in B.O.D germination chambers. The seeds of three cowpea cultivars: BRS Tumucumaque, BRS Aracê, and BRS Guariba, were germinated at five osmotic potentials $(0.0 ;-0.2 ;-0.4 ;-0.6$, and $-0.8 \mathrm{MPa})$ after three pre-treatments: pre-soaking in deionized water, pre-soaking in salicylic acid, and without pre-soaking. The following parameters were evaluated: germination, germination speed index, seedling height, total phytomass, contents of chlorophyll ' $a$ ' and ' $b$ ', carotenoid content, electrolyte leakage, water content, and proline content. Our results indicate that salicylic acid promotes reduction in the harmful effects of abiotic stress, which is reflected in the increase in germination percentage, seedling height, and chlorophyll and carotenoid content as well as in the adjustment of electrolyte leakage and increase in proline content under induced water stress conditions. The cultivar BRS Guariba proved to be more tolerant to water deficit during germination and initial growth stages, when the seeds were treated with salicylic acid $(1 \mathrm{mM})$.
\end{abstract}

Keywords: Vigna unguiculata. Water stress. Plant morphophysiology.

\section{GERMINAÇÃO E CRESCIMENTO INICIAL DE CULTIVARES DE FEIJÃO-CAUPI SOB ESTRESSE OSMÓTICO E ÁCIDO SALICÍLICO}

\begin{abstract}
RESUMO - O feijão-caupi é uma das principais culturas alimentares no Nordeste do Brasil, onde é geralmente cultivada nas regiões semiáridas com pouca disponibilidade de água. É importante estudar os elicitores associados ao caupi para mitigar os efeitos deletérios do estresse abiótico no estabelecimento inicial desta cultura. Neste estudo, buscaram-se avaliar as alterações morfofisiológicas em cultivares de caupi sob estresse osmótico com sementes embebidas em ácido salicílico. O teste de germinação foi realizado em câmaras de germinação B.O.D. As sementes de três cultivares de caupi: BRS Tumucumaque, BRS Aracê e BRS Guariba foram germinadas em cinco potenciais osmóticos $(0,0 ;-0,2 ;-0,4 ;-0,6$ e $-0,8 \mathrm{MPa})$ após três pré-tratamentos: pré-imersão em Água desionizada, pré-imersão em ácido salicílico e sem pré-imersão. Foram avaliados os seguintes parâmetros: germinação, índice de velocidade de germinação, altura da plântula, fitometria total, conteúdo de clorofila 'a' e 'b', conteúdo de carotenóides, vazamento eletrolítico, teor de água e conteúdo de prolina. Os resultados indicam que o ácido salicílico promove a redução dos efeitos nocivos do estresse abiótico, o que se reflete no aumento da porcentagem de germinação, altura da plântula e teor de clorofila e carotenóides, bem como no ajuste do vazamento eletrolítico e aumento do teor de prolina sob condições de estresse hídrico. A cultivar BRS Guariba mostrou-se mais tolerante ao déficit de água durante a germinação e estágios de crescimento inicial, quando as sementes foram tratadas com ácido salicílico (1 $\mathrm{mM})$.
\end{abstract}

Palavras-chave: Vigna unguiculata. Estresse hídrico. Morfofisiologia das plantas.

\footnotetext{
*Corresponding author

${ }^{1}$ Received for publication in 08/31/2016; accepted in 05/18/2017.

Paper approved from IV CONAC 2016.

${ }^{2}$ Department of Agrarian Sciences, Universidade Estadual da Paraíba, Campina Grande, PB, Brazil; araujo.biologiauebp@outlook.com, alberto@uepb.edu.br,marialirium@hotmail.com,rebecafc90@hotmail.com.

${ }^{3}$ Embrapa, Teresina, PI, Brazil; maurisrael.rocha@embrapa.br.
} 


\section{INTRODUCTION}

Cowpea (Vigna unguiculata L. Walp.) is an important leguminous species, which is predominantly cultivated in hot climates of semi-arid and sub-tropical regions of the world. It has high nutritional value due to the presence of various minerals and vitamins as well as the seeds' high protein content of up to $25 \%$ (AGBICODO et al., 2009). These characteristics make cowpea an important food crop for human consumption; however, it is prone to harm caused by drought and extreme temperatures. Thus, there is an increasing necessity for identifying and developing drought-tolerant cultivars of cowpea that are adapted to provide high yields under varying agroclimatic conditions (VALDEZ et al., 2012).

Compared to other common beans, such as Phaseolus vulgaris L., cowpea is a crop with low demand for water and nutrients (COSTA et al. 2011). However, under extreme water deficit conditions, cowpea plants exhibit production of antioxidants and cellular osmotic adjustment through the accumulation of compatible solutes in the cytosol (SHARMA et al., 2012), other than the reduction in leaf area and leaf water potential, stomatal closure, photosynthetic inhibition, and stunted root system growth (TAIZ; ZEIGER, 2013). According to McCue et al. (2000), osmotic stress on seeds can be mitigated by the application of endogenous or exogenous elicitors, which activate defense mechanisms during external attacks or pathogen infections. Major elicitors include organic acids, such as salicylic, ascorbic, jasmonic, and citric acid.

Salicylic acid is present in most plants (SHI et al., 2005) and has various functions, especially in the inhibition of germination and growth, and also in the absorption of solutes through the roots (ASHRAF et al., 2010). It plays an important role in the regulation of a number of physiological processes in the plant (SHI et al., 2005) and is an important component in the signals of translation of the main pathways for systemic acquired resistance (SONG et al., 2004).

Plants produce phytohormones, such as auxins, gibberellins, cytokinins, ethylene, and abscisic acid, which regulate growth and development. On the other hand, several molecules, such as jasmonic acid and salicylic acid, participate in the process of resistance to pathogens and defense against herbivores (TAIZ; ZEIGER, 2013). Research has confirm that salicylic acid is a plant hormone and growth regulator that, in small amounts, promotes, inhibits or modifies the physiological processes of the plants subjected to osmotic deficiency (GONÇALVES, 2013) and induces tolerance against biotic and abiotic stress factors (KANG; LI; GUO, 2014). Salicylic acid has been studied extensively to evaluate its capability to provide protection to plants, when they are subjected to water stress. These studies have been conducted in different agricultural crops, including common beans, by Agostini, Machado-Neto and Custódio (2013); in sesame, by Silva et al. (2017); and in cowpea, by Dutra et al. (2017) and Costa (2016).

This study aimed to evaluate the morphophysiological alterations in cowpea cultivars under osmotic stress and with seeds soaked in salicylic acid.

\section{MATERIAL AND METHODS}

The experiment was carried out from January to May 2016 at the Laboratory of Ecophysiology of Cultivated Plants (ECOLAB), Três Marias Integrated Research Complex, State University of Paraíba, Campus I, Campina Grande - PB, Brazil.

The treatments were prepared using the $3 \times 3 \times 5$ factorial design and included seeds of three cowpea cultivars (BRS Tumucumaque, BRS Aracê, and BRS Guariba) subjected to three conditions before sowing: $\mathrm{NS}=$ no soaking, $\mathrm{SA}=$ soaking in salicylic acid $(1.0 \mathrm{mM})$, and $\mathrm{DW}=$ soaking in deionized water. The treatments using soaking were kept for a period of $8 \mathrm{~h}$ and were subjected to five osmotic potentials induced by polyethylene glycol 6000 (PEG 6000) during germination and initial growth $[-0.8 ;-0.6 ;-0.4 ;-0.2 \mathrm{MPa}$, and $0 \mathrm{MPa}$ (deionized water)]. The experimental design was completely randomized, with four replicates for each treatment, and 50 seeds were used in each experimental plot (BRASIL, 2009).

Seeds were initially sorted to eliminate those with physical and biological damage and/or malformation. After sorting, the seeds were weighed and transferred to an axially rotating roll made of PVC tube, with a radius of $130 \mathrm{~cm}$. Fungicide (Captan $\left.{ }^{\circledR}\right)$ was applied to 200 seeds at the dose of

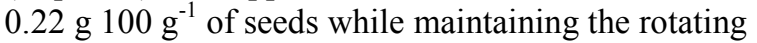
roll in rotation for $5 \mathrm{~min}$ followed by the seeds remaining at rest for $24 \mathrm{~h}$. After fungicide application, the seeds were divided into three portions, two of which were stored in paper towels in the form of rolls (BRASIL, 2009) for later soaking in salicylic acid solution $(1.0 \mathrm{mM})$ and in deionized water (DW) for a period of $8 \mathrm{~h}$. The third portion was stored in a sealed PET bottle for the same period to avoid any alteration in the moisture content of seeds.

After the soaking period, all seeds were distributed in acrylic boxes (Gerbox $\left.{ }^{\circledR}\right)$ with 50 seeds per box. The boxes contained four sheets of Germitest ${ }^{\circledR}$ paper, previously moistened with deionized water and osmotic solutions of PEG (-0.8; $-0.6 ;-0.4$ and $-0.2 \mathrm{MPa}$ ) with a proportion of $2.5 \mathrm{~g} \mathrm{~g}^{-1}$ of paper, and placed in Gerbox ${ }^{\circledR}$ plastic boxes. The boxes were sealed with plastic film and weighed on analytical scale to obtain the mass of the whole setup (set box + paper + seeds + plastic film). This mass was used to guide the daily water 
replacement in these boxes. The boxes were kept in B.O.D. (Biochemical Oxygen Demand) germination chambers that were set to have an artificial photoperiod of $12 \mathrm{~h}$ and light phase of $10 \mu \mathrm{mol} \mathrm{m} \mathrm{m}^{-2} \mathrm{~s}^{-1}$ of PAR (Photosynthetically Active Radiation) for 14 days (BRASIL, 2009). Water consumption was daily monitored by weighing the boxes followed by water replacement to maintain the overall mass at the initial measured mass.

The amount of polyethylene glycol (PEG 6000) necessary for each osmotic solution was determined using the equation proposed by Michel and Kaufmann (1973), obtaining the following values: 0.0 (deionized water) and the potentials of $-0.8,-0.6,-0.4$ and $-0.2 \mathrm{MPa}$. Dilution of PEG was performed in $200 \mathrm{~mL}$ of purified water $\left(25^{\circ} \mathrm{C}\right)$, which was subsequently mixed with $100 \mathrm{~mL}$ of the same solvent. The final solution was maintained in sealed glass flasks at room temperature, to minimize water loss and, consequently, to avoid alteration in the potential until used for analysis.

For 14 days, at the same time, germination counts were made considering only those seeds that had produced a radicle with a minimum length of $2 \mathrm{~mm}$ as germinated ones (REHMAN et al., 1996). This data was used to calculate germination percentage and germination speed index (GSI) (CARVALHO; CARVALHO, 2009).

After measuring the lengths of seedlings, the stems were separately arranged in paper bags and placed in a forced-air oven at $65^{\circ} \mathrm{C}$ for $48 \mathrm{~h}$. Thereafter, total phytomass (TP) was measured by weighing on an analytical scale.

The relative water content of leaves was evaluated as described by Smart and Bingham (1974). Cell membrane integrity was determined using the methodology proposed by Campos and Thi (1997), which is based on electrolyte leakage and expressed as percentage of conductivity in relation to the total conductivity. Total ' $a$ ' and ' $b$ ' chlorophyll and carotenoids were extracted using the solvent dimethyl sulfoxide (HISCOX; ISRAELSTAM, 1979). The quantification of free proline in the tissues was performed by the colorimetric method proposed by Bates, Waldren and Teare (1973) and modified by Bezerra Neto and Barreto (2011).

The data on response variables were subjected to analysis of variance by $\mathrm{F}$ test $(p \leq 0.05)$. Regression models, for the quantitative factor, were fitted according to the determination coefficient up to the significance level of 0.05 . For the analyses and graphs, the programs, Sisvar, Excel, and Table Curve $2 \mathrm{D}$ were used.

\section{RESULTS AND DISCUSSION}

Figure $1(b, d, f)$ shows the reductions in the GSI of the cultivars, BRS Tumucumaque, BRS Aracê, and BRS Guariba. The trendline illustrates a reduction in osmotic potential (Figure 1a, c, e). Water stress contributed to the decrease in seed germination percentage and, for each species, there is a value of soil water potential below which germination does not occur (ÁVILA et al., 2010). The cultivar, BRS Aracê, (Figure 1c) exhibited short germination times i.e., high GSI, at the highest potentials: $0.0 \mathrm{MPa}$ (control), $-0.2 \mathrm{MPa}$, and $-0.4 \mathrm{MPa}$. At the potential of $-0.4 \mathrm{MPa}$, there was a higher GSI, in the order of 2.11. An increase in the germination time was observed at lower potentials, which significantly differed for the potentials, $-0.6 \mathrm{MPa}$ and -0.8 MPa. Similar results were obtained for the cultivar, BRS Tumucumaque (Figure 1a), which showed higher increase in germination times i.e., lower GSI, as the osmotic potentials decreased and differed significantly only at the potentials of $0.0 \mathrm{MPa}$ (control) and $-0.2 \mathrm{MPa}$. These findings are consistent with those of Teixeira et al. (2011), who evaluated germination and vigor of crambe (Crambe abyssinica Hochst) seeds, under conditions of PEG 6000-induced water stress with solutions from 0.0 to $-1.4 \mathrm{MPa}$, and found that reduction in the osmotic potential of the substrate promoted significant reduction in germination efficiency and vigor of crambe seeds.

Osmotic potentials equal to or lower than $-0.6 \mathrm{MPa}$ were detrimental to seed germination because they prevented the development of normal seedlings. However, the cultivar, BRS Guariba, was more tolerant to water stress. In this context, water restriction was observed to increase the time of germination and reduce germination efficiency as the osmotic potential was lowered. This can be attributed to reduction in the speed of metabolic and biochemical processes under water deficient conditions, which retards or inhibits seed germination (ÁVILA et al., 2010), a fact that may have occurred with the evaluated cowpea cultivars. 

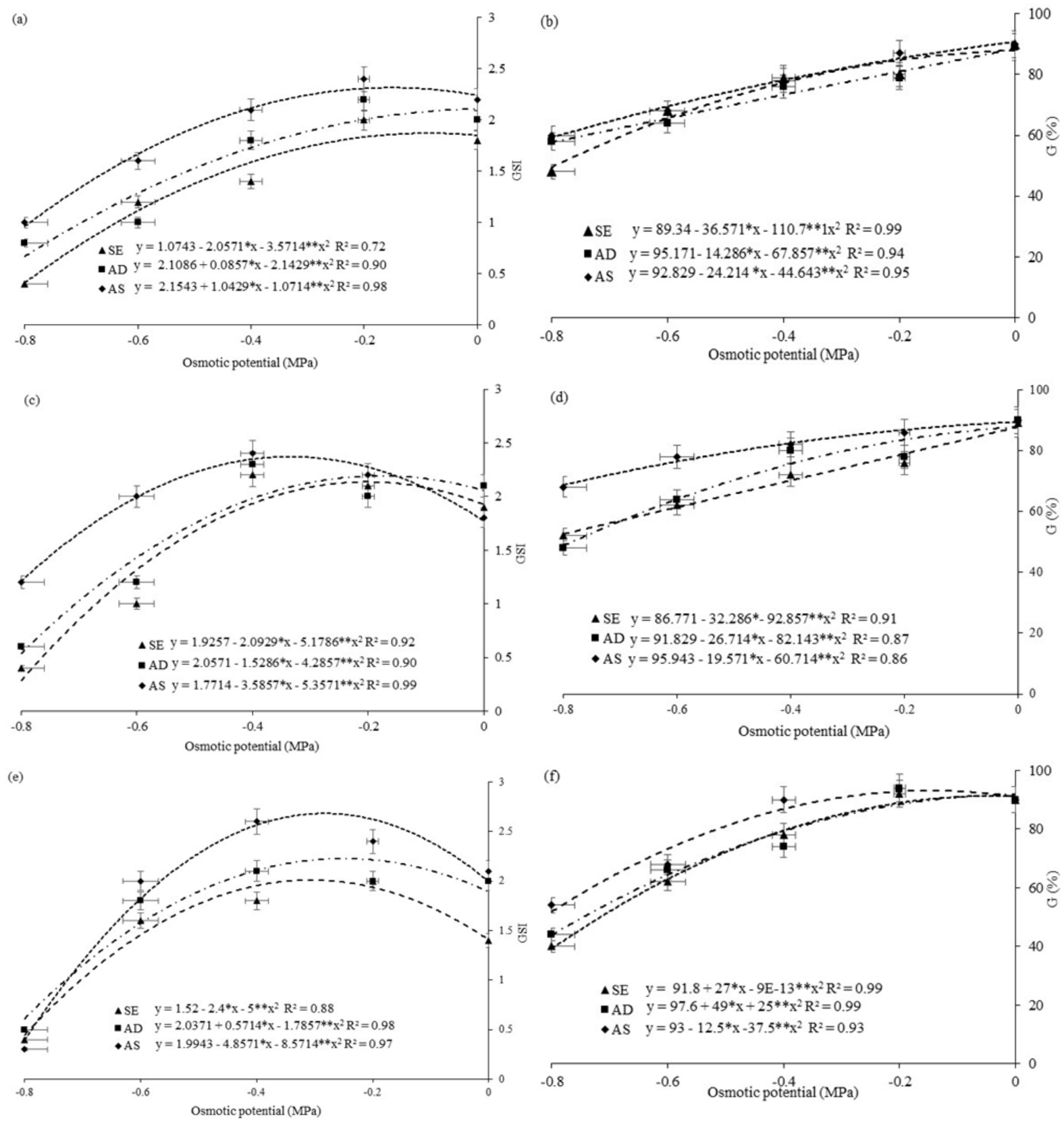

Figure 1. Germination speed index - GSI (a, c, e) and germination percentage - G (b, d, f) of the cowpea cultivars: BRS Tumucumaque (a, b), BRS Aracê (c, d) and BRS Guariba (e, f), conditioned during the pre-sowing and subjected to different water potentials induced by PEG 6000. NS - no soaking; DW - soaking in deionized water and SA - soaking in salicylic acid.

According to the follow-up analysis of the effect of soaking for each cowpea cultivar, the cultivar, BRS Tumucumaque, showed a reduction of $33.84 \%$ in seedling height, when the seeds were soaked in salicylic acid (Figure 2a). The cultivar, BRS Aracê, exhibited the opposite behavior with highest estimated value of height $(11.98 \mathrm{~cm})$ at the potential of $-0.4 \mathrm{MPa}$. There was a $24.78 \%$ increase in seedling height as compared to those grown as control $(0 \mathrm{MPa})$. As the osmotic potential decreased from -0.4 MPa, seedling height also decreased with a significant reduction of $35.71 \%$ in seedling height at $-0.8 \mathrm{MPa}$ (Figure 2c). The highest estimated height was $14.2 \mathrm{~cm}$ at the osmotic potential of $-0.4 \mathrm{MPa}$, representing a $37.93 \%$ increase in seedling height for BRS Aracê. For the cultivar BRS Guariba, seedling height of $15.30 \mathrm{~cm}$ was observed at the potential of $-0.4 \mathrm{MPa}$. After the maximum point of the curve, which corresponds to the potentials below $-0.4 \mathrm{MPa}$, there was a reduction of $40.74 \%$ in relation to the critical value $(13 \mathrm{~cm})$ of seedling height, when the concentration was $-0.4 \mathrm{MPa}$ (Figure 2e).

As the seedlings grew, there was a directly proportional gain of phytomass in all the three cultivars studied (Figure 2b, d, f). These results indicate symmetry in the growth of shoots and roots 
per seedling. Thus, when there is significant correlation between both features, it is possible to estimate increase in one of them through the indirect selection of the other. Such estimated correlations allow researchers to determine the associations between structures of plants, which provide the basis for the establishment of a genetic improvement plan under conditions of water limitation in soil (RODRIGUES et al., 2010).
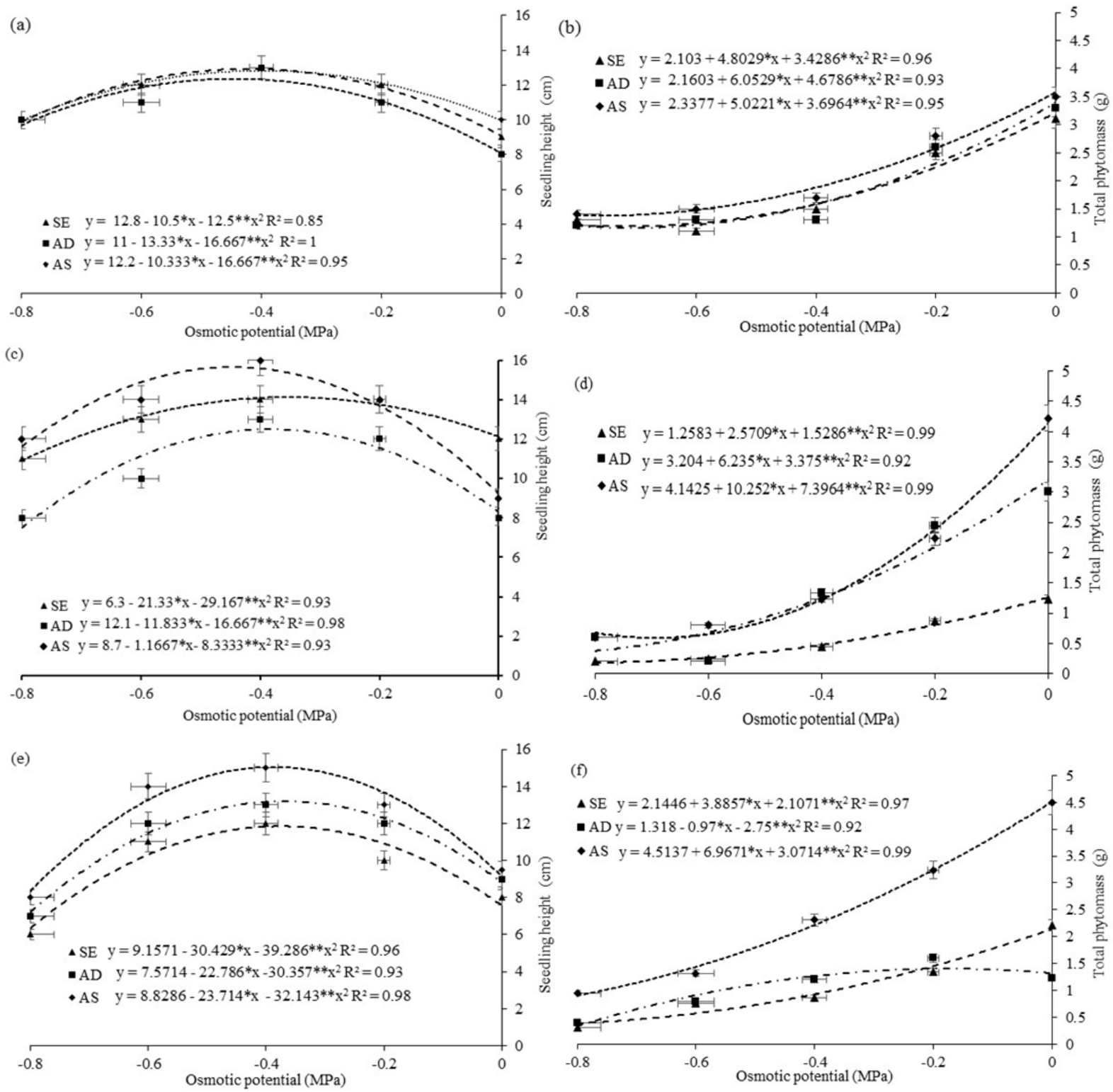

Figure 2. Seedling height (a, c, e) and total phytomass (b, d, f) of cowpea cultivars: BRS Tumucumaque (a, b), BRS Aracê (c, d) and BRS Guariba (e, f), conditioned during the pre-sowing and subjected to different water potentials induced by PEG 6000. NS - no soaking; DW - soaking in deionized water and SA - soaking in salicylic acid.

Taiz and Zeiger (2013) reported that cell membrane extrusion leads to loss of ions from guard cells. This phenomenon is mostly due to the increase in osmotic potential and surrounding temperature because this stress negatively impacts cell turgor. Silva et al. (2015) similarly reported that an increase in temperature may lead to various metabolic disorders and, consequently, to the rupture of cell membrane and leakage of intracellular electrolytes.

In the present study, the interaction between osmotic potential and soaking with salicylic acid revealed the occurrence of electrolyte leakage from the cell up to 55,39 and $54 \%$ at the potential of $-0.8 \mathrm{MPa}$ for the cultivars, BRS Tumucumaque, BRS Aracê, and BRS Guariba', respectively 
(Figure 3a, c, e). Among the cultivars that received salicylic acid, BRS Tumucumaque showed $80 \%$ of leaked electrolytes. Furthermore, the relative water content (Figure $3 \mathrm{~b}, \mathrm{~d}, \mathrm{f}$ ) in the presence of salicylic acid was also altered; the cultivars BRS
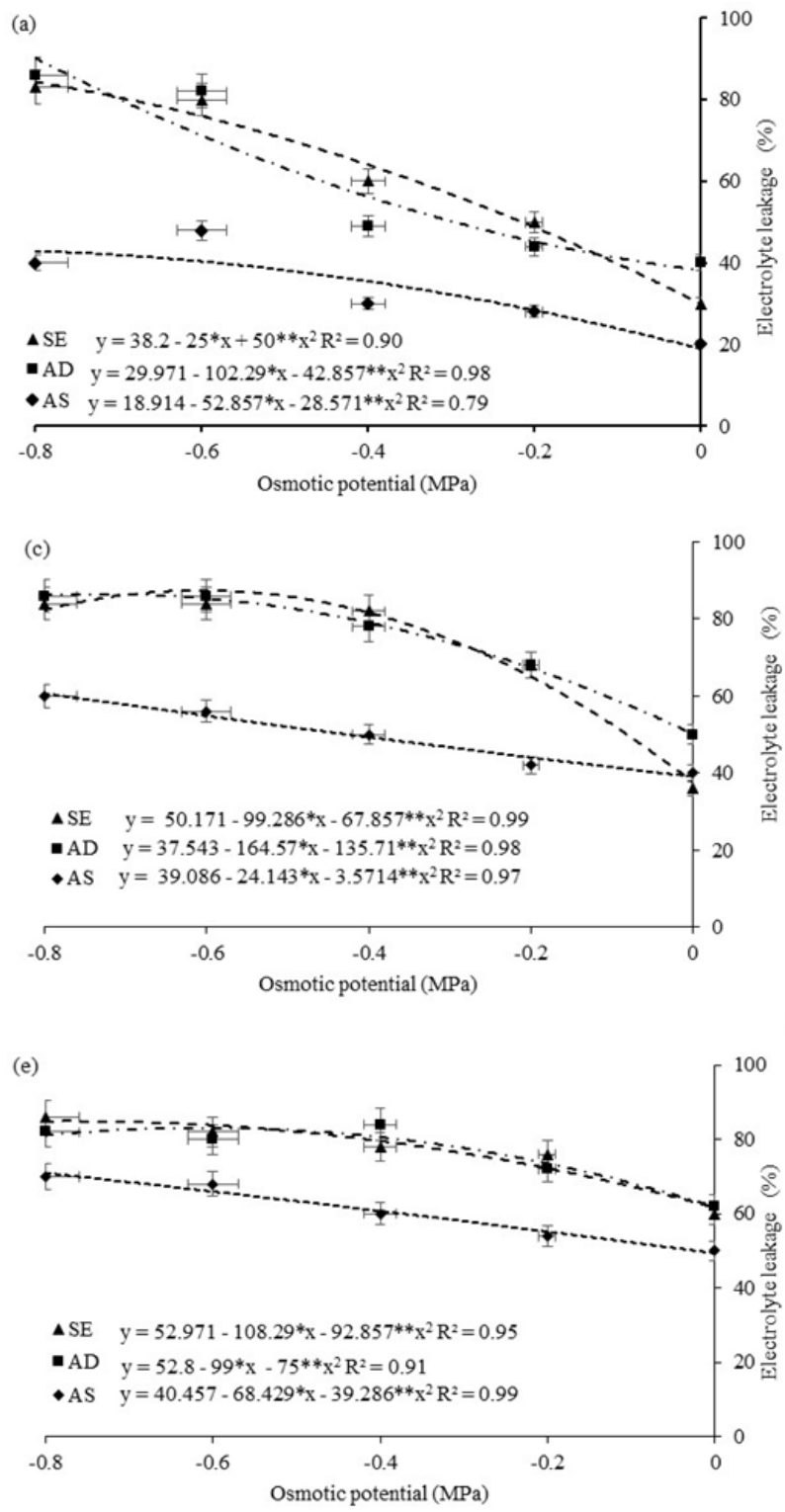

Tumucumaque and BRS Aracê exhibited similar behavior at the potential of $-0.4 \mathrm{MPa}$, showing relative water content of 40 and $41 \%$, respectively. In the cultivar, BRS Guariba, relative water content increased by $50 \%$ at the potential of $-0.6 \mathrm{MPa}$.
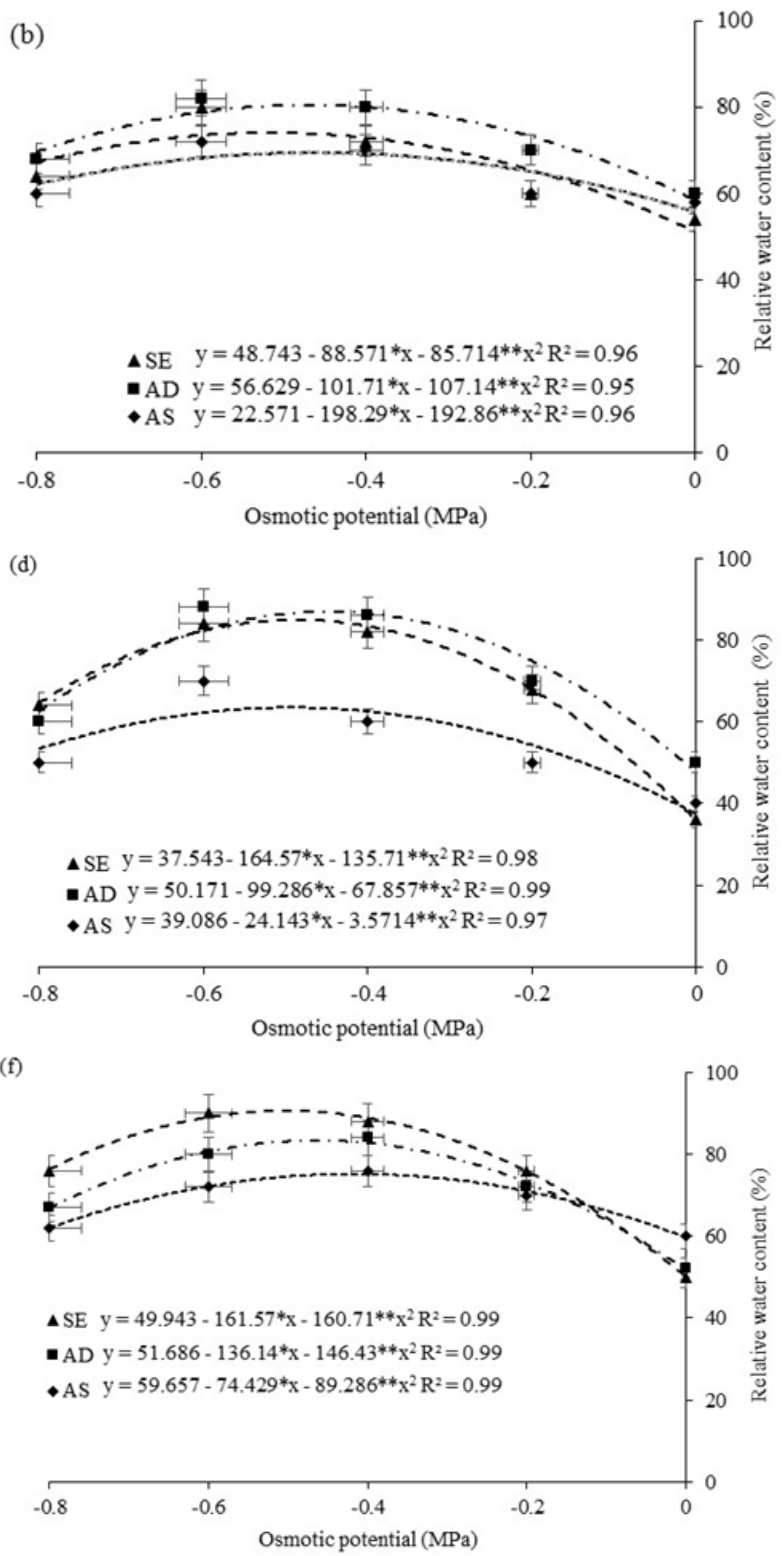

Figure 3. Electrolyte leakage $(a, b, e)$ and relative water content $(b, d, f)$ of the cowpea cultivars: BRS Tumucumaque (a, b), BRS Aracê (c, d) and BRS Guariba (e, f), conditioned during the pre-sowing and subjected to different water potentials induced by PEG 6000 . NS - no soaking; DW - soaking in deionized water and SA - soaking in salicylic acid.

The highest content of chlorophyll 'a' (504.24 $\left.\mu \mathrm{mol} \mathrm{m}{ }^{-2}\right)$ was observed in BRS Aracê, when soaked in salicylic acid at a potential of $-0.4 \mathrm{MPa}$. This value contrasted with the critical value of chlorophyll ' $\mathrm{a}$ ' $\left(272.33 \mu \mathrm{mol} \mathrm{m} \mathrm{m}^{-2}\right)$ found at the potential of $-0.8 \mathrm{MPa}$. In the interval between the minimum and maximum potential points, a $37.50 \%$ increase in increase in chlorophyll ' $a$ ' content was estimated (Figure 4c). BRS Guariba seedlings, when treated with salicylic acid, showed chlorophyll 'a' content of $273.33 \mu \mathrm{mol} \mathrm{m}{ }^{-2}$. With the increase in the PEG 6000 concentrations in the spray solution, a significant increase in chlorophyll ' $\mathrm{a}$ ' content $(23.33 \%)$ was observed, with an estimated value of $200 \mu \mathrm{mol} \mathrm{m}{ }^{-2}$ at the potential of $-0.8 \mathrm{MPa}$. Beyond this point, the increase in salicylic acid concentration led to a $33.33 \%$ increase in chlorophyll ' $a$ ' content, with a maximum value of $300 \mu \mathrm{mol} \mathrm{m} \mathrm{m}^{-2}$ estimated for the soaking in salicylic acid at osmotic potential of $-0.4 \mathrm{MPa}$ (Figure 4e). Furthermore, the cultivar 
BRS Tumucumaque showed alterations in its chlorophyll ' $a$ ' content similar to that of BRS Guariba. There was a $25 \%$ decrease in chlorophyll ' $a$ ' content, compared with the value of $300 \mu \mathrm{mol} \mathrm{m} \mathrm{m}^{-2}$ measured in seedlings without salicylic acid application and a value of $366.98 \mu \mathrm{mol} \mathrm{m} \mathrm{m}^{-2}$ for seedlings with salicylic acid soaking and potential of $-0.4 \mathrm{MPa}$.

Mean chlorophyll ' $b$ ' content in the three cultivars, BRS Tumucumaque, BRS Aracê, and BRS Guariba fitted to the quadratic model $\left(\mathrm{R}^{2}=0.98\right)$ $\left(\mathrm{R}^{2}=0.92\right)$ and $\left(\mathrm{R}^{2}=0.85\right)$. The highest contents, $32.09 \mu \mathrm{mol} \mathrm{m} \mathrm{m}^{-2}, 61.56 \mu \mathrm{mol} \mathrm{m} \mathrm{m}^{-2}$, and $71.31 \mu \mathrm{mol} \mathrm{m} \mathrm{m}^{-2}$, respectively, were observed in plants that were not subjected to application of salicylic acid. The use of salicylic acid to soak the seeds caused reductions in chlorophyll ' $b$ ' content up

(a)

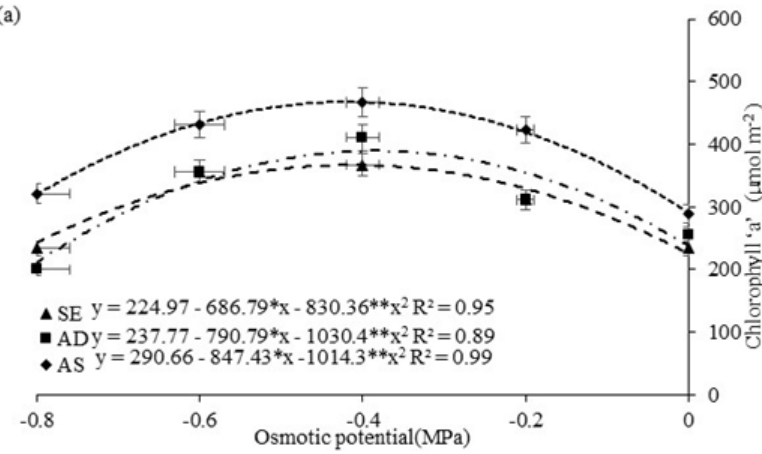

(c)

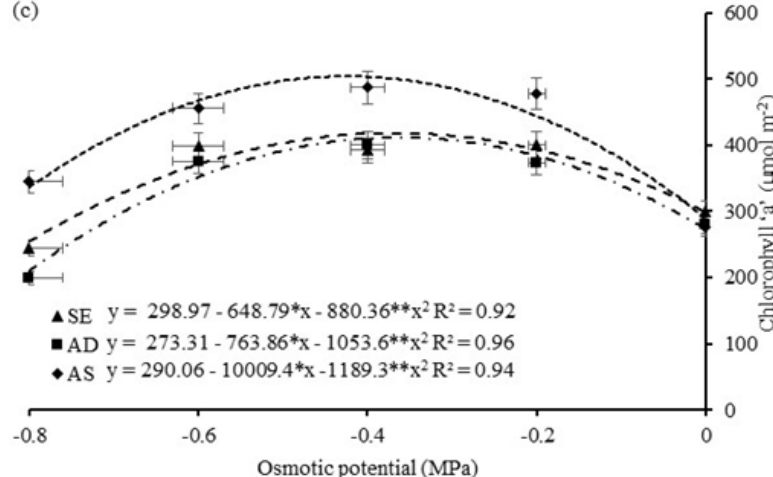

(c)

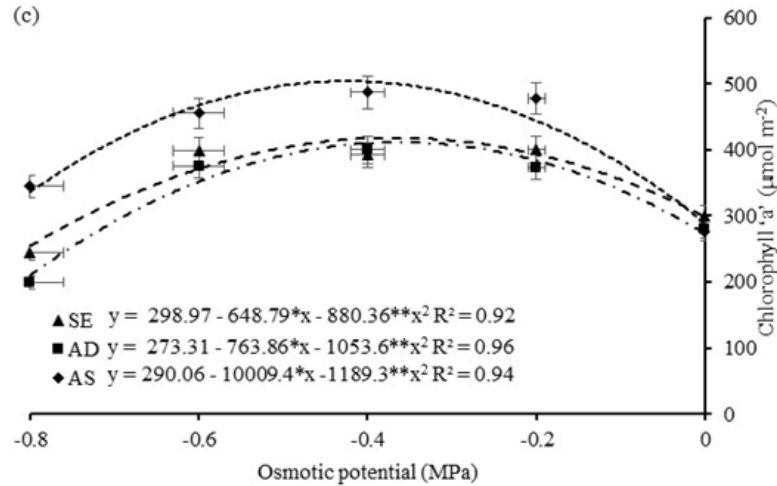

to $22.09 \%$ in BRS Tumucumaque, $46.39 \%$ in BRS Aracê, and 57.93\% in BRS Guariba, with estimated critical values of $24.5 \mu \mathrm{mol} \mathrm{m}{ }^{-2}, 31.5 \mu \mathrm{mol} \mathrm{m} \mathrm{m}^{-2}$, and $30.0 \mu \mathrm{mol} \mathrm{m} \mathrm{m}^{-2}$, respectively, of this pigment at the induced stress of $-0.8 \mathrm{MPa}$ (Figure $4 \mathrm{~b}, \mathrm{~d}, \mathrm{f}$ ).

Carotenoids are accessory pigments produced by plants to aid chlorophyll to capture light (TAIZ; ZEIGER, 2013). According to Paiva et al. (2005), carotenoids are responsible for protect plants against oxidative damages and are used by the plant's defense system. Their production is generally increased when the production of chlorophyll ' $a$ ' and ' $b$ ' is compromised. Hence, it can be inferred that an increase in carotenoid content in response to salicylic acid application indicates the optimization of the cowpea plant's defense mechanism.

(b)
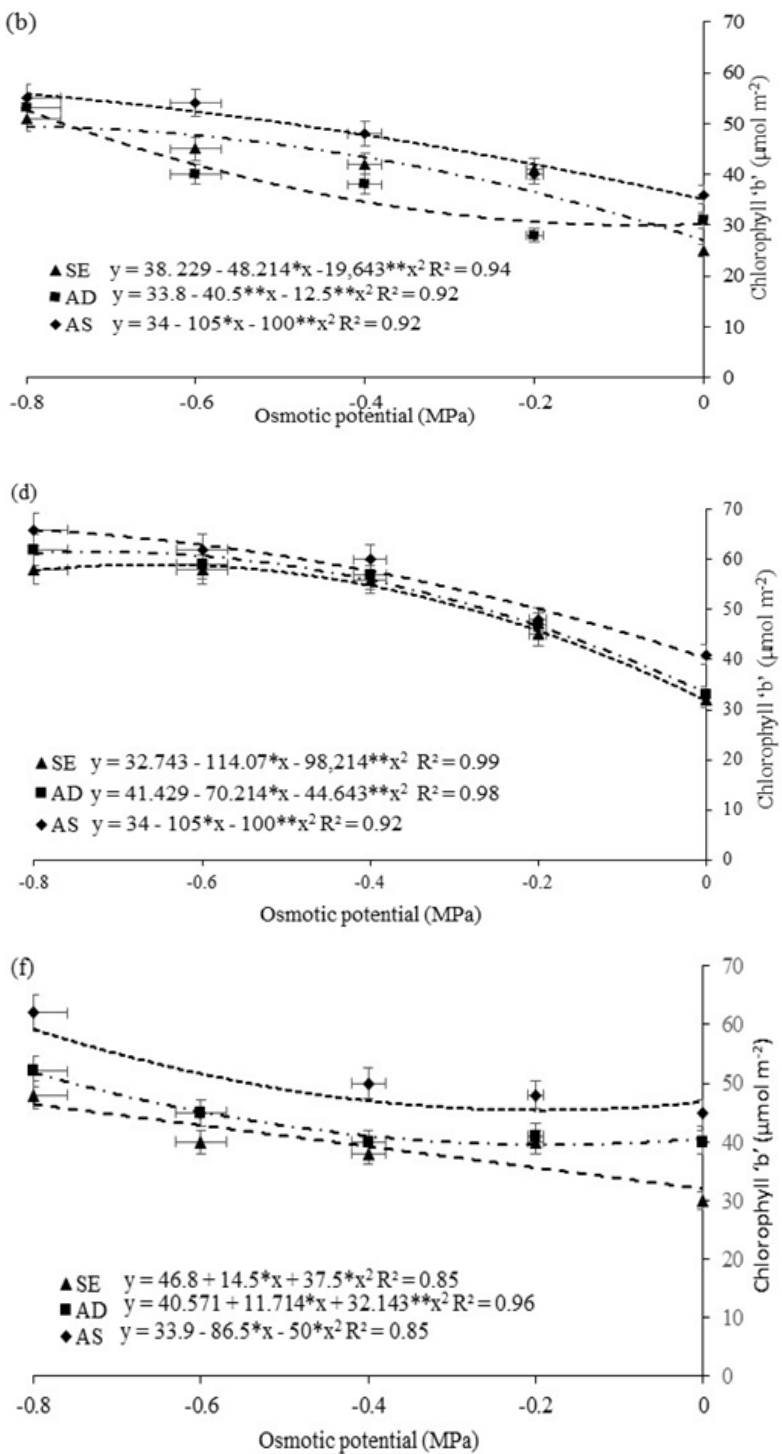

Figure 4. Contents of chlorophyll ' $a$ ' ( $a, c, e)$ and chlorophyll ' $b$ ' (b, d, f) of the cowpea cultivars: BRS Tumucumaque $(a, b)$, BRS Aracê (c, d) and BRS Guariba (e, f), conditioned during the pre-sowing and subjected to different water potentials induced by PEG 6000. NS - no soaking; DW - soaking in deionized water and SA - soaking in salicylic acid. 
All three cultivars exhibited an increase in proline content at the osmotic potential of $-0.8 \mathrm{MPa}$. BRS Aracê fitted the quadratic polynomial model $\left(\mathrm{R}^{2}=0.98\right)$ (Figure $\left.5 \mathrm{~b}, \mathrm{~d}, \mathrm{f}\right)$. According to Figure $5 \mathrm{~b}$, there is a sharp increase in the free proline content $(51.4 \%)$ at the osmotic potential of $-0.8 \mathrm{MPa}$. Figure $5 \mathrm{f}$ shows the trend curve for the proline content in

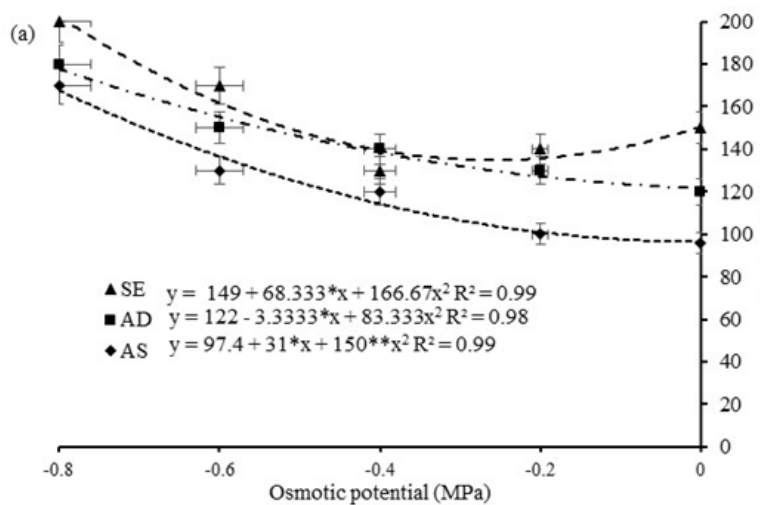

(c)
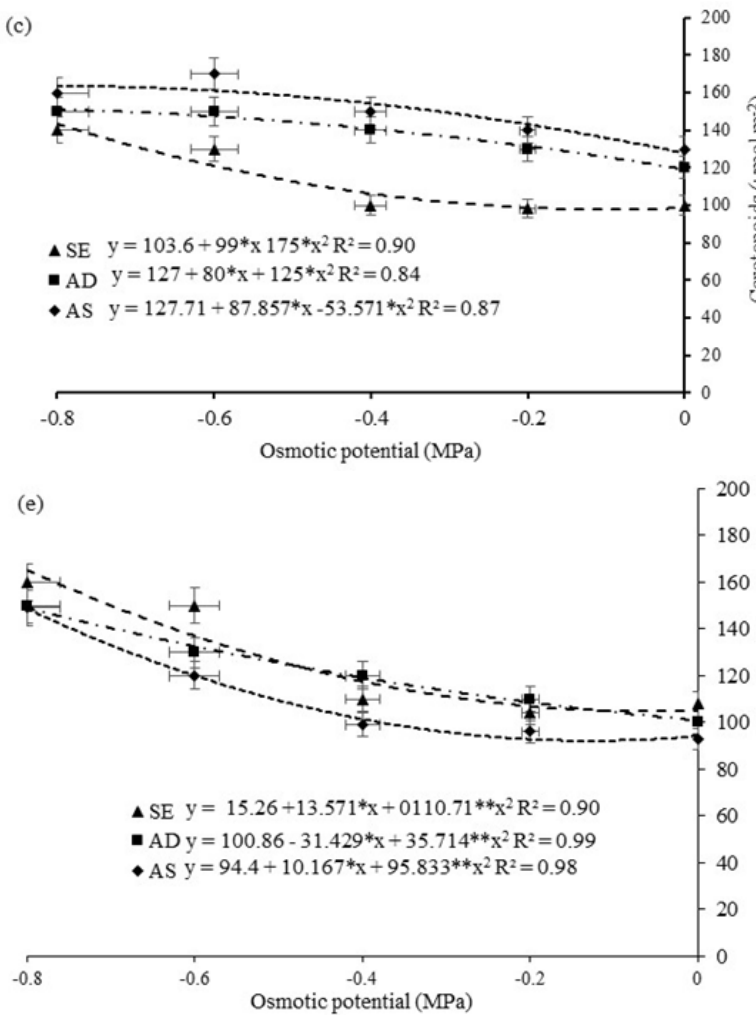

response to the defense mechanism of BRS Guariba soaked in salicylic acid. In this cultivar, the maximum proline content $(55 \mu \mathrm{mol} \mathrm{g}$ of fresh matter ${ }^{-1}$ ) occurred at the osmotic potential of $-0.8 \mathrm{MPa}$ associated with the salicylic acid concentration of $1.0 \mathrm{mM}$
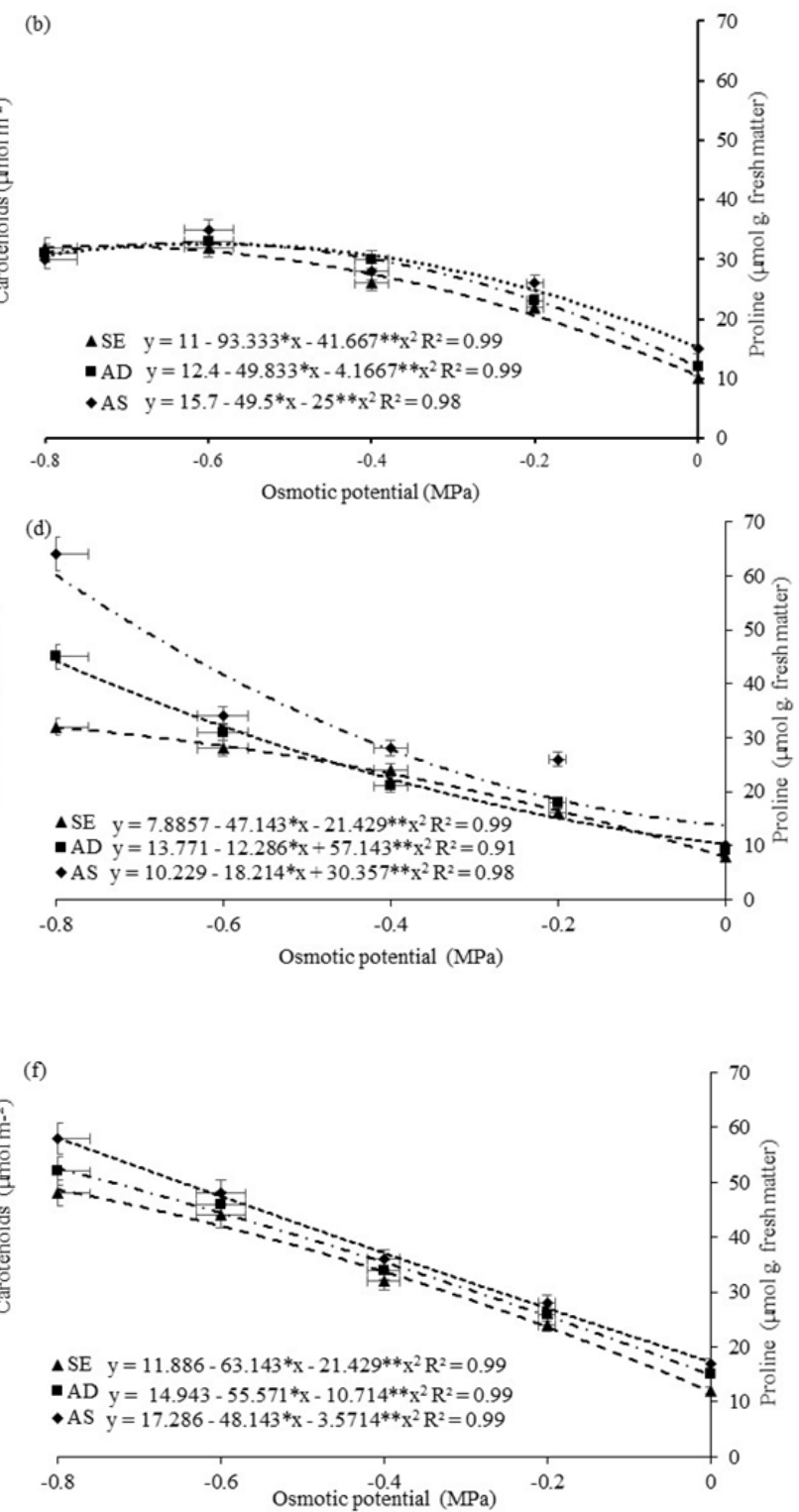

Figure 5. Content of carotenoids (a, c, e) and proline (b, d, f) of the cowpea cultivars: BRS Tumucumaque (a, b), BRS Aracê (c, d) and BRS Guariba (e, f), conditioned during the pre-sowing and subjected to different water potentials induced by PEG 6000 . NS - no soaking; DW - soaking in deionized water and SA - soaking in salicylic acid.

\section{CONCLUSION}

Salicylic acid promoted reduction in the harmful effects of the abiotic stress, which was reflected by the increase in germination percentage, seedling height, and contents of chlorophyll 'a', 'b,' and carotenoids. It also played an important role in the adjustment of cellular electrolyte leakage and in the increase in proline content under conditions of induced water stress. Among the evaluated cowpea cultivars, BRS Guariba was more tolerant to water deficit during germination and initial growth stages, when its seeds were treated with salicylic acid (1 $\mathrm{mM})$. 


\section{ACKNOWLEDGMENTS}

To the State University of Paraíba (UEPB), Laboratory (ECOLAB), for providing the infrastructure and staff; to the National Council for Scientific and Technological Development (CNPq), for granting the scholarship (DCR), and to the Paraíba Research Support Foundation (FAPESQ), for the financial support.

\section{REFERENCES}

AGBICODO, E. M. et al. Breeding drought tolerant cowpea: Constraints, accomplishments, and future prospects. Euphytica, Wageningen, v. 167, n. 1, p. 353-370, 2009.

AGOSTINI, E. A. T.; MACHADO-NETO, N. B.; CUSTÓDIO, C. C. Induction of water deficit tolerance by cold shock and salicylic acid during germination in the common bean. Acta Scientiarum Agronomy, Maringá, v. 35, n. 2, p. 209-219, 2013.

ASHRAF, M. et al. The physiological, biochemical and molecular roles of brassinosteroids and salicylic acid in plant processes and salt tolerance. Critical Reviews in Plant Sciences, Abington, v. 29, n. 3, p. 162-190, 2010.

ÁVILA, F. et al. Interação entre silício e nitrogênio em arroz cultivado sob solução nutritiva. Revista Ciência Agronômica, Fortaleza, v. 41, n. 2, p. 184190, 2010.

BATES, L. S.; WALDREN, R. P.; TEARE, I. D. Rapid determination of free proline for water-stress studies. Short communication. Plant and Soil, Cham, v. 39, n. 1, p. 205-207, 1973.

BEZERRA NETO, E.; BARreto, L. P. Análises químicas e bioquímicas em plantas. 1. ed. Recife, PE: UFRPE, 2011. 267 p.

BRASIL. Ministério da Agricultura, Pecuária e Abastecimento. Regras para Análise de Sementes. Secretaria de Defesa Agropecuária. Brasília: MAPA/ ACS, 2009. 395 p.

CAMPOS, P. S.; THI, A. T. P. Effect of abscisic acid pretreatment on membrane leakage and lipid composition of Vigna unguiculata leaf discs subjected to osmotic stress. Plant Science, Amsterdam, v. 130, n. 1, p. 11-18, 1997.

CARVALHO, R. I. N.; CARVALHO, D. B. Germinação de sementes de um ecótipo de Paspalum da região de Guarapuava- PR. Semina: Ciências Agrárias, Londrina, v. 30, n. 4, p. 1187-1194, 2009.
COSTA, R. C. L. et al. ABA mediated proline synthesis in cowpea leaves exposed to water deficiency and rehydration. Turkish Journal of Agriculture \& Forestry, Ankara, v. 35, n. 3, p. 309317,2011 .

COSTA, R. R. Atenuação de estresse hídrico em plantas de feijão-caupi tratadas com ácido salicílico. 2016. 89 f. Dissertação (Mestrado em Ciências Agrárias: Área de Concentração em Agrobionergia e Agricultura Familiar) Universidade Estadual da Paraíba, Campina Grande, 2016

DUTRA, W. F. et al. Antioxidative responses of cowpea cultivars to water deficit and salicylic acid treatment. Agronomy Journal, Madison, v. 109, n. 3, p. 895-905, 2017.

GONÇALVES, K. S. Aplicação de reguladores vegetais e de fosfito de potássio em mudas de eucalipto submetidas à deficiência hídrica. 2013. 80 f. Tese (Doutorado em Agronomia: Área de Concentração em Irrigação e Drenagem) Universidade Estadual Paulista, Botucatu, 2013.

HISCOX, J. D.; ISRAELSTAM, G. F. A method for the extraction of chlorophyll from leaf tissue without maceration. Canadian Journal of Botany, Ottawa, v. 57, n. 12 , p. $1332-1334,1979$.

KANG, G.; LI, G.; GUO, T. Molecular mechanism of salicylic acid-induced abiotic stress tolerance in righer plants. Acta Physiology Plantarum, Cham, v. 36 , n. 9, p. 2287-2297, 2014

MCCUE, P. et al. Model for enhanced pea seedling vigour following low $\mathrm{pH}$ and salicylic acid treatments. Processes Biochemistry, Amsterdam, v. 35 , n. 6 , p. 603-613, 2000

MICHEL, B. E.; KAUFMANN, M. R. The osmotic potential of polyethylene glycol 6000. Plant Physiology, Rockville, v. 51, n. 5, p. 914-916, 1973.

PAIVA, A. S. et al. Condutância estomática em folhas de feijoeiro submetido à diferentes regimes de irrigação. Engenharia Agrícola, Jaboticabal, v. 25, n. 1, p. 161-169, 2005.

REHMAN, S. et al. The effect of sodium chloride on germination and the potassium and calcium contents of Acacia seeds. Seed Science and Technology, Zurich, v. 25, n. 1, p. 45-57, 1996.

RODRIGUES, H. C. et al. Correlações genotípicas, fenotípicas e ambientais entre caracteres de mamoneira. Ciência e Agrotecnologia, Viçosa, v. 34, n. 6, p. 1390-1395, 2010 
SILVA, A. C. et al. Salicylic acid as attenuator of drought stress on germination and initial development of sesame. Revista Brasileira de Engenharia Agrícola e Ambiental, Campina Grande, v. 21, n. 3, p. 156-162, 2017.

SILVA, F. V. F. et al. Photosynthetic pigments and gas exchange in castor bean under conditions of above the optimal temperature and high $\mathrm{CO}_{2}$. Acta Scientiarum: Agronomy, Maringá, v. 37, n. 3, p. 331-337, 2015.

SHARMA, P. et al. Reactive oxygen species, oxidative damage, and antioxidative defense mechanism in plants under stressful conditions. Journal of Botany, London, v. 12, n. 1, p. 1-26, 2012.

SHI, Q. et al. Effects of different treatments of salicylic acid on heat tolerance, chlorophyll fluorescence, and antioxidant enzyme activity in seedlings of Cucumis sativa L. Russian Journal of Plant Physiology, Heidelberg, v. 52, n. 2, p. 793$800,2005$.

SMART, R. E.; BINGHAM, G. E. Rapid Estimates of Relative Water Content. Plant Physiology, Rockville, v. 53, n. 2, p. 258-260, 1974.

SONG, J. T. et al. A key role for ALD1 in activation of local and systemic defenses in Arabidopsis. Plant Journal, Lansing, v. 40, n. 1, p. 200-212, 2004.

TAIZ, L.; ZEIGER, E. Fisiologia vegetal. 5. ed. Porto Alegre, RS: Artmed, 2013. 918 p.

TEIXEIRA, R. N. et al. Germinação e vigor de sementes de crambe sob estresse hídrico. IRRIGA: Brazilian Jornal of irrigation and Drainage, Botucatu, v. 16, n. 1, p. 45-52, 2011.

VALDEZ, V. et al. Adaptation of grain legumes to climatic change: a review. Agronomy for Sustainable Development, Berlin, v. 32, n. 1, p. 3144, 2012. 